\title{
Public Perceptions of Mangrove Forests Matter for Their Conservation
}

\section{OPEN ACCESS}

Edited by:

José M. Riascos,

University of Antioquia, Colombia

Reviewed by:

Syed Ainul Hussain,

Wildlife Institute of India, India

*Correspondence:

Farid Dahdouh-Guebas

fdahdouh@ulb.ac.be;

Farid.Dahdouh-Guebas@ulb.be

Specialty section:

This article was submitted to

Global Change and the Future Ocean,

a section of the journal

Frontiers in Marine Science

Received: 07 September 2020

Accepted: 06 October 2020

Published: 19 November 2020

Citation:

Dahdouh-Guebas F, Ajonina GN, Amir AA, Andradi-Brown DA, Aziz I,

Balke T, Barbier EB, Cannicci S,

Cragg SM, Cunha-Lignon M,

Curnick DJ, Duarte CM, Duke NC,

Endsor C, Fratini S, Feller IC,

Fromard F, Hugé J, Huxham M,

Kairo JG, Kajita T, Kathiresan K,

Koedam N, Lee SY, Lin H-J,

Mackenzie JR, Mangora MM

Marchand C, Meziane T,

Minchinton TE, Pettorelli N, Polanía J,

Polgar G, Poti M, Primavera J,

Quarto A, Rog SM, Satyanarayana B,

Schaeffer-Novelli Y, Spalding M, Van

der Stocken $T$, Wodehouse $D$,

Yong JWH, Zimmer M and Friess DA

(2020) Public Perceptions of

Mangrove Forests Matter for Their

Conservation.

Front. Mar. Sci. 7:603651

doi: 10.3389/fmars.2020.603651

\author{
Farid Dahdouh-Guebas 1,2,3*, Gordon N. Ajonina ${ }^{3,4,5}$, A. Aldrie Amir ${ }^{3,6}$,
}

Dominic A. Andradi-Brown ${ }^{3,7}$, Irfan Aziz ${ }^{3,8}$, Thorsten Balke ${ }^{3,9}$, Edward B. Barbier ${ }^{3,10}$, Stefano Cannicci ${ }^{3,11,12}$, Simon M. Cragg ${ }^{3,13}$, Marilia Cunha-Lignon ${ }^{3,14}$, David J. Curnick ${ }^{3,15}$, Carlos M. Duarte ${ }^{16}$, Norman C. Duke ${ }^{3,17}$, Charlie Endsor ${ }^{3,15}$, Sara Fratini ${ }^{3,12}$, Ilka C. Feller ${ }^{3,18}$, François Fromard ${ }^{3,19}$, Jean Hugé ${ }^{1,2,20}$, Mark Huxham ${ }^{3,21}$, James G. Kairo ${ }^{3,22}$, Tadashi Kajita ${ }^{3,23}$, Kandasamy Kathiresan ${ }^{3,24}$, Nico Koedam ${ }^{2,3}$, Shing Yip Lee ${ }^{3,25}$, Hsing-Juh Lin ${ }^{3,26}$, Jock R. Mackenzie ${ }^{27}$, Mwita M. Mangora ${ }^{3,28,29}$, Cyril Marchand ${ }^{3,30}$, Tarik Meziane ${ }^{3,31}$, Todd E. Minchinton ${ }^{3,32}$, Nathalie Pettorelli, ${ }^{3,15}$, Jaime Polanía, ${ }^{3,33}$, Gianluca Polgar ${ }^{3,34}$, Meenakshi Poti ${ }^{1,2,20}$, Jurgenne Primavera ${ }^{3,35}$, Alfredo Quarto ${ }^{3,36}$, Stefanie M. Rog ${ }^{37}$, Behara Satyanarayana ${ }^{1,3,38}$, Yara Schaeffer-Novelli,39, Mark Spalding ${ }^{3,40,41}$, Tom Van der Stocken ${ }^{2}$, Dominic Wodehouse ${ }^{3,36}$, Jean W. H. Yong ${ }^{3,42}$, Martin Zimmer ${ }^{3,43,44}$ and Daniel A. Friess ${ }^{3,45}$

${ }^{1}$ Systems Ecology and Resource Management Research Unit, Département de Biologie des Organismes, Université Libre de Bruxelles - ULB, Brussels, Belgium, ${ }^{2}$ Ecology \& Biodiversity, Laboratory of Plant Biology and Nature Management, Biology Department, Vrije Universiteit Brussel - VUB, Brussels, Belgium, ${ }^{3}$ Mangrove Specialist Group, Species Survival Commission, International Union for the Conservation of Nature, London, United Kingdom, ${ }^{4}$ Department of Aquatic Ecosystems Management, Institute of Fisheries and Aquatic Sciences, University of Douala, Yabassi, Cameroon, ${ }^{5}$ Cameroon Wildife Conservation Society, Coastal Forests and Mangrove Programme, Mouanko, Cameroon, ${ }^{6}$ Institute for Environment and Development (LESTARI), Universiti Kebangsaan Malaysia, Bangi, Malaysia, ${ }^{7}$ Ocean Conservation, World Wildlife Fund, Washington, DC, United States, ${ }^{8}$ Dr. M Ajmal Khan Institute of Sustainable Halophyte Utilization, University of Karachi, Karachi, Pakistan, ${ }^{9}$ School of Geographical and Earth Sciences, University of Glasgow, Glasgow, United Kingdom, ${ }^{10}$ Department of Economics, Colorado State University, Fort Collins, CO, United States, ${ }^{11}$ The Swire Institute of Marine Science, The University of Hong Kong, Hong Kong, Hong Kong, ${ }^{12}$ Department of Biology, University of Florence, Sesto Fiorentino, Italy, ${ }^{13}$ Institute of Marine Sciences, University of Portsmouth, Portsmouth, United Kingdom, ${ }^{14}$ Department of Fishery Engineering, Universidade Estadual Paulista, Registro, Brazil, ${ }^{15}$ Institute of Zoology, Zoological Society of London, London, United Kingdom, ${ }^{16}$ Red Sea Research Center and Computational Bioscience Research Center, King Abdullah University of Science and Technology, Thuwal, Saudi Arabia, ${ }^{17}$ TropWATER Centre, James Cook University, Townsville, QLD, Australia, ${ }^{18}$ Smithsonian Institution, Smithsonian Environmental Research Center, Edgewater, MD, United States,

${ }^{19}$ Laboratoire Écologie Fonctionnelle et Environnement, Université de Toulouse, CNRS, Toulouse, France, ${ }^{20}$ Department of Environmental Science, Open University of the Netherlands, Heerlen, Netherlands, ${ }^{21}$ School of Applied Sciences, Edinburgh Napier University, Edinburgh, Scotland, United Kingdom, ${ }^{22}$ Kenya Marine and Fisheries Research Institute, Mombasa, Kenya, ${ }^{23}$ Iriomote Station, Tropical Biosphere Research Center, University of the Ryukyus, Okinawa, Japan, ${ }^{24}$ Centre of Advanced Study in Marine Biology, Annamalai University, Parangipettai, India, ${ }^{25}$ Simon F S Li Marine Science Laboratory, The Chinese University of Hong Kong, Sha Tin, Hong Kong, ${ }^{26}$ Department of Life Sciences, National Chung Hsing University, Taichung, Taiwan, ${ }^{27}$ MangroveWatch Ltd, Currumbin, QLD, Australia, ${ }^{28}$ Institute of Marine Sciences, University of Dar es Salaam, Dar es Salaam, Tanzania, ${ }^{29}$ Western Indian Ocean Mangrove Network, Institute of Marine Sciences, Zanzibar, Tanzania, ${ }^{30}$ Institute of Pure and Applied Sciences (ISEA), University of New Caledonia, Noumea, New Caledonia, ${ }^{31}$ Laboratoire de Biologie des Organismes et Ecosystèmes Aquatiques (BOREA), Muséum National d'Histoire Naturelle, CNRS UMR 7208 IRD 207, SU, UA, UCN, Paris, France, ${ }^{32}$ Centre for Sustainable Ecosystem Solutions, University of Wollongong, Wollongong, NSW, Australia, ${ }^{33}$ Departamento de Ciencias Forestales, Universidad Nacional de Colombia, Sede Medellín, Medellín, Colombia, ${ }^{34}$ CNR IRSA Water Research Institute, Verbania, Italy, ${ }^{35}$ Zoological Society of London, Iloilo City, Philippines, ${ }^{36}$ Mangrove Action Project, Port Angeles, WA, United States, ${ }^{37}$ Wetlands International, Wageningen, Netherlands, ${ }^{38}$ Mangrove Research Unit, Institute of Oceanography and Environment, Universiti Malaysia Terengganu, Kuala Terengganu, Malaysia,

${ }^{39}$ Oceanographic Institute, University of São Paulo, São Paulo, Brazil, ${ }^{40}$ The Nature Conservancy and Department of Zoology, University of Cambridge, Cambridge, United Kingdom, ${ }^{41}$ Department of Physical, Earth Environmental Sciences, University of Siena, Siena, Italy, ${ }^{42}$ Department of Biosystems and Technology, Swedish University of Agricultural Sciences, Alnarp, Sweden, ${ }^{43}$ Leibniz Centre for Tropical Marine Research, Bremen, Germany, ${ }^{44}$ Faculty 02 Biology/Chemistry, University of Bremen, Bremen, Germany, ${ }^{45}$ Department of Geography, National University of Singapore, Singapore, Singapore

Keywords: ecosystem service, ecosystem disservice, social media, communication, mangrove 


\section{INTRODUCTION}

Iconic species and landscapes attract public attention to help reverse the degradation of ecosystems and their biodiversity (Thompson and Rog, 2019); sharing their images on social media can act as a powerful way to influence perceptions and drive positive actions by the public (Wu et al., 2018). Social media platforms such as Twitter, Facebook and Instagram have been used to great effect to communicate the urgency required to halt and reverse tropical forest loss (Lamb et al., 2005) and the plight of coral reefs (Curnock et al., 2019). Ecosystems such as seagrass meadows, mudflats, and mangrove forests receive substantially less media exposure (Duarte et al., 2008). Yet these under-recognized ecosystems are hugely important for local and global societies, providing benefits such as shoreline protection (Barbier, 2016), fisheries (Carrasquilla-Henao and Juanes, 2017), carbon capture and storage (Duarte et al., 2013), alongside supporting rich marine and terrestrial biodiversity (Sievers et al., 2019; Thompson and Rog, 2019) (Figure 1). Apart from these important ecosystem functions, goods and services, mangrove forests are home to a huge diversity of organisms with ecologically and evolutionarily unique adaptations to life in the intertidal zone, including vivipary and salt tolerance in trees, air-breathing in crabs and amphibious behavior in fish (mudskippers); this makes mangrove forests a dynamic and fascinating evolutionary laboratory.

Despite our improved understanding of the importance of mangrove forests and their ecosystem services, negative perceptions of these wetlands are still common. We highlight the dangers of recurrent public misperceptions about mangroves and how they can be countered. The authors represent a variety of stakeholders involved in the research and communication of mangrove forests through academia, government agencies and non-governmental organizations involved in conservation.

\section{DANGERS OF MISPERCEPTIONS}

Misinformed and biased public communication has important implications for environmental management. Historically, mangrove forests have been cast in a negative light due to their (often perceived) ecosystem disservices (Friess et al., 2020a), such as being habitats for dangerous animals (like crocodiles, tigers, and snakes) and insects (like mosquitoes and sandflies) that act as vectors for disease. Descriptions of mangroves as a source of putrid exhalations indicative of death to come have been around since at least the nineteenth century (Darwin, 1839; Friess, 2016). Such views have contributed to the large-scale clearance and drainage of mangrove forests and their conversion to aquaculture, agriculture or areas for infrastructure and urban development in ever more human-dominated land and seascapes. Mangrove loss occurred under the assumption that such interventions were converting dangerous and valueless wastelands into more directly economical uses, as a way of controlling nature and harnessing these areas for human use (Friess et al., 2020a).

Even though we now have an improved understanding of the value of mangroves to nature and society, the legacy of negative perceptions can still be reinforced through social media, where influential users, actors, and decision-makers have the potential to share opinions that may unintentionally or intentionally revive past aversions. For example, a recent Twitter post promoted mangroves as a provider of key benefits to society, despite the negative perception that "Mangroves are not pretty to look at, subjectively speaking..." . Though stylistically intended to immediately emphasize their importance, this preceding description implicitly endorses negative perceptions. Such framing continues to be used as a communication strategy, where negative terminology is used as an introduction to an otherwise positive commentary about mangroves: "Ugly, smelly, overlooked"2, "seen as unproductive and smelly", "Mangroves don't inspire awe and wonder... In many parts of the world, they've long been frowned upon as dirty, mosquito-infested tangles of roots that stand in the way of an ocean view"4. While intended as a riposte to the historically negative perceptions of mangroves, such a framing to grab the attention of a reader may have unintended consequences for, or undermine, future conservation efforts.

\section{DISCUSSION ON THE WAY FORWARD}

Public and stakeholder awareness of both the beauty and importance of mangroves has in many places moved on from such misperceptions. Mangrove forests are a national conservation priority in several countries, with ambitious protection targets announced in countries such as Sri Lanka ${ }^{5}$ and Indonesia ${ }^{6}$. Mangroves are high on the international policy agenda and are frequently discussed in the context of international climate change agreements (Herr and Landis, 2016). Mangrove forests are now often showcased in documentaries to educate the public. In situ appreciation of mangroves by the public is shown by the huge increase in mangrove ecotourism around the world. Tourists enjoy visiting mangrove forests in what has become a multi-billion dollar industry, with over 37,000 TripAdvisor reviews mentioning mangroves across nearly 4,000 mangrove attractions world-wide (Spalding and Parrett, 2019).

Clearly, many coastal management stakeholders and the public have moved beyond historical perceptions of mangroves. We suggest that it is time for research and conservation advocacy to recognize this wider shift in public perception of mangroves along with the power of social media and to move toward more nuanced forms of messaging to reflect this. We must be

\footnotetext{
${ }^{1}$ Available online at: https://twitter.com/IucnOcean/status/ 1248146633369489408?ref_src=twsrc\%5Etfw (accessed April 09, 2020).

${ }^{2}$ Available online at: https://forestsnews.cifor.org/31178/indonesian-mangrovesspecial-fact-file-a-global-treasure- under-threat? $\mathrm{fnl}=($ accessed October 01,2020$)$.

${ }^{3}$ Available online at: https://wwf.panda.org/our_work/oceans/coasts/mangroves/ mangrove_threats/ (accessed October 01, 2020).

${ }^{4}$ Available online at: https://www.conservation.org/blog/6-things-you-need-toknow-about-mangroves-but-never-thought-to-ask (accessed October 01, 2020). ${ }^{5}$ Available online at: https://www.bbc.com/news/science-environment-36885914 (accessed October 01, 2020).

${ }^{6}$ Available online at: https://en.antaranews.com/news/152466/mangrove-foreststo-hereafter-not-be-converted-into-ponds-minister (accessed October 01, 2020).
} 


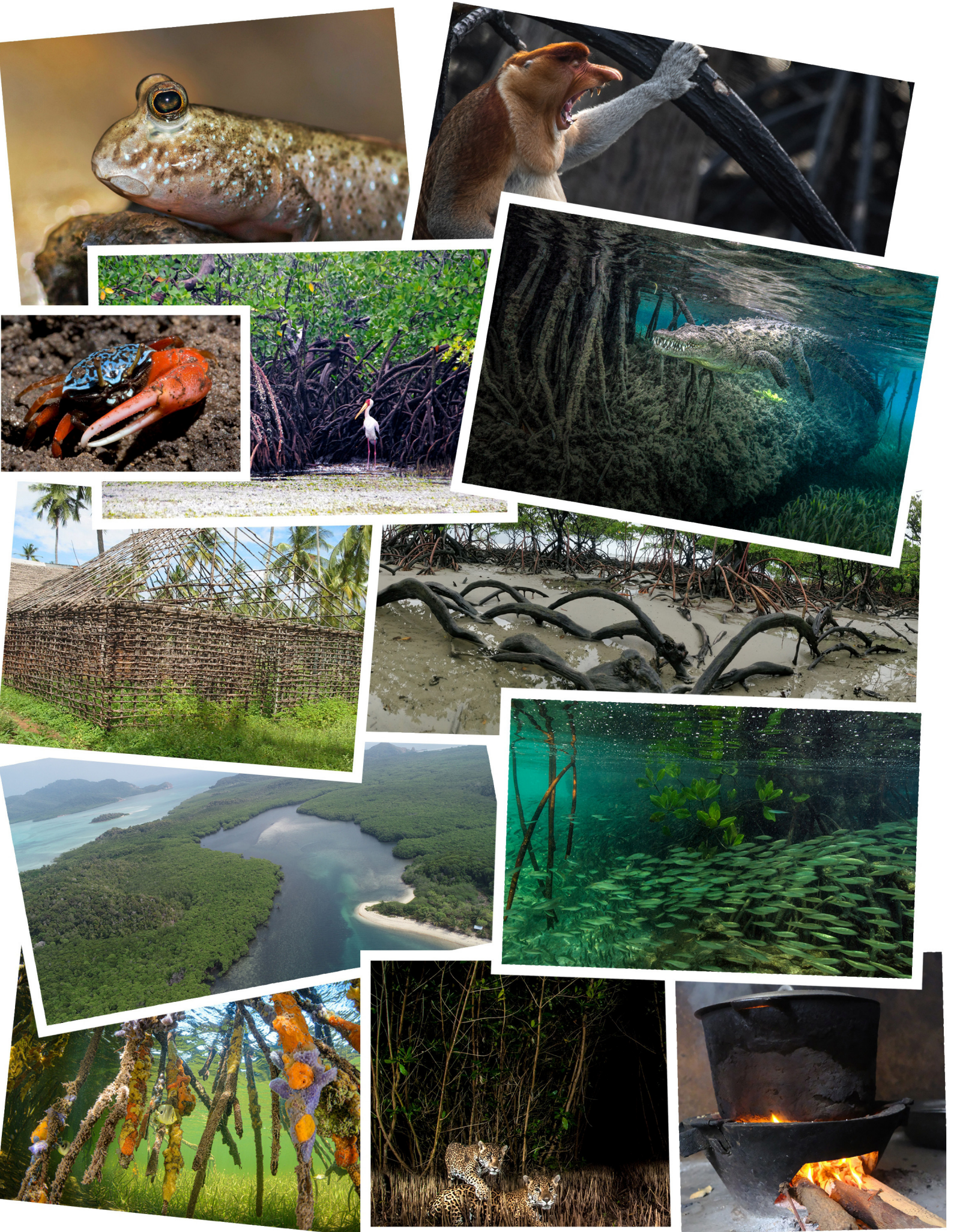

FIGURE 1 | Mangroves are a cornucopia of life-a rainforest by the sea-surviving in intertidal zones of tropical and subtropical regions. A healthy mangrove forest is inspiring to pass through. One may wind through countless branching waterways or channels that cut through the tangle of mangrove roots and branches, watch the foraging storks, egrets and spoonbills wading through the mud, and the roosting kingfishers and herons in the arching canopy, observe mudskippers contest in

(Continued) 
FIGURE 1 | mini-battles for territory, and catch sight of monitor lizards racing across the glistening surface of mudflats toward the safety of deeper pools. Or walk in the mud at low tide, losing more than one sandal to the thick ooze of the mangrove substrate that can sink you thigh-deep in places. Look for fresh footprints of jaguars between the aerial roots in Latin American mangroves or of Bengal tigers in mud channels where they crossed in the Sundarbans, or watch proboscis monkeys peering from trees in Borneo, and immense sea crocodiles launching themselves from primordial shores in emerald enclaves of India's Bhitarkanika sanctuary. Mangroves are also the markets for traditional communities, providing building materials, fuelwood, tannins, medicinal remedies, and food such as Crassostrea brasiliana. They also protect shorelines and property from storm damage and erosion and prevent silt and polluted runoff from reaching fragile coral reefs and seagrass beds. The mangrove root complex serves as breeding, spawning, hatching, and nursing habitat for fish and other organisms. Mangroves are also amazing carbon sinks, sequestering up to five times the amount of carbon than any other forest type, storing that carbon for millennia. Photo locations and credits from top to bottom and from left to right: India (Arghyadeep Das), Borneo, Indonesia (Anil T. Prabhakar), Gazi Bay, Kenya (Stefano Cannicci), Gazi Bay, Kenya (Dominic Wodehouse), Jardines de la Reina, Cuba (Jenny Stock), Gazi Bay, Kenya (Griet Neukermans), Cape Tribulation, Queensland, Australia (Mohammed Hisham Shaikh), Pulau Seri Buat, Pahang, Malaysia (Ahmad Aldrie Amir), South Button, Andaman Archipelago, India (Umeed Mistry), Grand Cayman, Cayman Islands (Eiko Jones), Nayarit, Mexico (Victor H. Luja Molina), Toubacouta, Sine Saloum, Senegal (Dominic Wodehouse). A high resolution version of each separate photograph is in Supplementary Figures 1-12.

vigilant against messages propagating negative perceptions of ecosystems or emphasizing disservices and short-term economic losses. Where the conservation of endangered ecosystems such as mangroves, mudflats, seagrass meadows, salt marshes, coral reefs, and tropical rainforests is at risk and in need of increasing public support, the continuing reference to negative perceptions may fuel under-valuation and lead to further habitat loss.

There are exciting opportunities for researchers, stakeholders, and communication specialists to work together to frame mangroves and similar ecosystems in ways that represent current perceptions and best promote their conservation. In the same way as science can provide frameworks that reconcile nature, people and policy to aid management and governance of mangrove systems (Dahdouh-Guebas et al., 2020), we should provide a framework bringing together public perceptions and conservation needs. For example, posting high-quality images of charismatic, iconic and evolutionarily peculiar species (Thompson and Rog, 2019) that can act as "ambassadors" on social media has been identified as an efficient way to highlight biological features and conservation status and to foster public awareness (Wu et al., 2018) (Figure 1). We commend the particularly strong communication strategy highlighting the fragility and beauty of mangrove forests by the $\mathrm{BBC}^{7}$. It must indeed be efficiently communicated that a loss of mangroves implies both a scientific loss of eco-evolutionary important organisms and habitat characteristics and a loss of benefits to society. Promoting positive perceptions by highlighting the valuable functions, goods and services and the long-term

\footnotetext{
${ }^{7}$ Available online at: https://www.bbc.com/news/in-pictures- 54241533 (accessed October 01, 2020).
}

economic and social benefits that these endangered ecosystems provide, will ultimately underpin successful conservation (Bennett, 2016) and instill optimism in conservation efforts (Friess et al., 2020b).

\section{AUTHOR'S NOTE}

As per Frontiers style the affiliations are listed in the order that they appear in the affiliations list. Therefore note that the IUCN Species Survival Commission's Mangrove Specialist Group (3) is the secondary or tertiary affiliation for each of the authors.

\section{AUTHOR CONTRIBUTIONS}

All authors contributed to the writing of the paper under coordination of FD-G.

\section{ACKNOWLEDGMENTS}

Many thanks are due to Leo Thom (Mangrove Action Project) for assembling Figure 1. The authors acknowledge the 12 photographers of the photos indicated in the caption of Figure 1 and the numerous online posters of inspiring mangrove photographs and stories.

\section{SUPPLEMENTARY MATERIAL}

The Supplementary Material for this article can be found online at: https://www.frontiersin.org/articles/10.3389/fmars. 2020.603651/full\#supplementary-material

\section{REFERENCES}

Barbier, E. B. (2016). The protective service of mangrove ecosystems: a review of valuation methods. Mar. Pollut. Bull. 109, 676-681. doi: 10.1016/j.marpolbul.2016.01.033

Bennett, N. J. (2016). Using perceptions as evidence to improve conservation and environmental management. Conserv. Biol. 30, 582-592. doi: 10.1111/cobi. 12681

Carrasquilla-Henao, M., and Juanes, F. (2017). Mangroves enhance local fisheries catches: a global meta-analysis. Fish Fish. 18, 79-93. doi: 10.1111/faf. 12168

Curnock, M. I., Marshall, N. A., Thiault, L., Heron, S. F., Hoey, J., Williams, G., et al. (2019). Shifts in tourists' sentiments and climate risk perceptions following mass coral bleaching of the Great Barrier Reef. Nat. Clim. Chang 9, 535-541. doi: 10.1038/s41558-019-0504-y

Dahdouh-Guebas, F., Hugé J., Abuchahla, G. M. O., Cannicci, S., Jayatissa, L. P., Kairo, J. G., et al. (2020). Reconciling nature, people and policy in the mangrove social-ecological system through the adaptive cycle heuristic. Estuar. Coast. Shelf Sci. 247:106942. doi: 10.1016/j.ecss.2020.106942

Darwin, C. R. (1839). Journal of Researches Into the Natural History and Geology of the Countries Visited During the Voyage of H.M.S. Beagle Round the World, Under the Command of Capt. Fitz Roy, R.N. London: John Murray. 
Duarte, C. M., Dennison, W. C., Orth, R. J. W., and Carruthers, T. J. B. (2008). The charisma of coastal ecosystems: addressing the imbalance. Estuaries Coasts 31, 233-238. doi: 10.1007/s12237-008-9038-7

Duarte, C. M., Losada, I. J., Hendriks, I. E., Mazarrasa, I., and Marbà, N. (2013). The role of coastal plant communities for climate change mitigation and adaptation. Nat. Clim. Chang. 3, 961-968. doi: 10.1038/nclimate1970

Friess, D. A. (2016). Ecosystem services and disservices of mangrove forests: insights from historical colonial observations. Forests 7:183. doi: 10.3390/f7090183

Friess, D. A., Yando, E. S., Abuchahla, G. M. O., Adams, J. B., Cannicci, S., Canty, S. W. J., et al. (2020b). Mangroves give cause for conservation optimism, for now. Curr. Biol. 30, R135-R158. doi: 10.1016/j.cub.2019.12.054

Friess, D. A., Yando, E. S., Alemu, J. B., Wong, L.-W., Soto, S. D., and Bhatia, N. (2020a). Ecosystem services and disservices of mangrove forests and saltmarshes. Oceanogr. Mar. Biol. 58, 107-142. doi: 10.1201/978042935 1495-3

Herr, D., and Landis, E. (2016). Coastal Blue Carbon Ecosystems. Opportunities for Nationally Determined Contributions. Policy Brief. Gland; Washington, DC: IUCN, TNC.

Lamb, D., Erskine, P. D., and Parrotta, J. A. (2005). Restoration of degraded tropical forest landscapes. Science 310, 1628-1632. doi: 10.1126/science.1111773

Sievers, M., Brown, C. J., Tulloch, V. J. D., Pearson, R. M., Haig, J. A., Turschwell, M. P., et al. (2019). The role of vegetated coastal wetlands for marine megafauna conservation. Trends Ecol. Evol. 34, 807-817. doi: 10.1016/j.tree.2019. 04.004
Spalding, M., and Parrett, C. L. (2019). Global patterns in mangrove recreation and tourism. Mar. Policy 110:103540. doi: 10.1016/j.marpol.2019.103540

Thompson, B. S., and Rog, S. M. (2019). Beyond ecosystem services: using charismatic megafauna as flagship species for mangrove forest conservation. Environ. Sci. Policy 102, 9-17. doi: 10.1016/j.envsci.2019.09.009

Wu, Y., Yie, L., Huang, S.-L., Li, P., Yuan, Z., and Liu, W. (2018). Using social media to strengthen public awareness of wildlife conservation. Ocean Coastal Manage. 153, 76-83. doi: 10.1016/j.ocecoaman.2017.12.010

Conflict of Interest: The authors declare that the research was conducted in the absence of any commercial or financial relationships that could be construed as a potential conflict of interest.

Copyright (C) 2020 Dahdouh-Guebas, Ajonina, Amir, Andradi-Brown, Aziz, Balke, Barbier, Cannicci, Cragg, Cunha-Lignon, Curnick, Duarte, Duke, Endsor, Fratini, Feller, Fromard, Hugé, Huxham, Kairo, Kajita, Kathiresan, Koedam, Lee, Lin, Mackenzie, Mangora, Marchand, Meziane, Minchinton, Pettorelli, Polaní, Polgar, Poti, Primavera, Quarto, Rog, Satyanarayana, Schaeffer-Novelli, Spalding, Van der Stocken, Wodehouse, Yong, Zimmer and Friess. This is an open-access article distributed under the terms of the Creative Commons Attribution License (CC BY). The use, distribution or reproduction in other forums is permitted, provided the original author(s) and the copyright owner(s) are credited and that the original publication in this journal is cited, in accordance with accepted academic practice. No use, distribution or reproduction is permitted which does not comply with these terms. 